\title{
Zis \\ THE PRESENT IMPACT AND SIGNIFICANT OF FINANCIAL LITERACY: A COMPARATIVE STUDIED ON PERFORMANCE ANALYSIS OF LISTED PRIVATE AND PUBLIC BANK IN INDIA
}

\author{
Mijarul Islam \\ E-Mail Id: islammijarul2012@gmail.com \\ Assistant Professor, Barasat College, West Bengal, India
}

\begin{abstract}
The study focused on the fundamental analysis of different company with the same sector or industry. The prime objective of this study are to find out the best future perspective and expected good future growth compare to other with the based on historical performance. Selected two banking company which is listed in Indian stock exchange and over the ten year financial data. Considered four indicator of barometer of the companies are: earning per share, dividend per share, return on equity and return on assets. Used mean difference of each variable for the purpose of testing the significant of the variable of this study. On the basis of the financial data and limited period of the study might be concluding that private bank focused good signal then public bank. But in our study conducted very small sample only two bank, in case of large sample it's may be opposite result.
\end{abstract}

Keywords: Fundamental analysis ,NSE, ROA, ROE, Dividend Payout, EPS.

\section{INTRODUCTION}

In the portfolio management, it is very important to find out the suitable investment place where fund will grow with the less risk. For that purpose every fund manager performs that's duty carefully. Who are coming from market research or portfolio management specially on the financial performance of firm like balance sheet, profit and loss account and financial performance analysis etc. they known as well how to read the financial performance of a company but in case a general investor how to invest his money it's a big question. For this purpose the journey of this study to find out a common way. In this study used both technical and fundamental analysis for selection the investment opportunity as general.

\section{LITERATURE REVIEW}

Bhattacharya et. al (1997) examined that the productivity efficiency of 70 Indian commercial banks during 1986 to 1991. Used Data Evolvement Analysis (DEA), the studied conclude that public sector banks have been the most efficient followed then the private banks.

Miller \& Modigliani (1961) argued that under certain simplifying assumptions, the dividend decision does not affect the value of a firm and is, hence, unimportant. Yet, traditional wisdom with changed postulations advocates that a properly managed dividend policy is vital to shareholders because it can affect share prices and shareholder's wealth. This argument is based upon two assumptions that there is no tax disadvantage to an investor to receiving dividends, and the second is that firms can raise funds in capital markets for new investments without bearing significant issuance costs. The proponents of the second school feel that dividends are bad for the average stockholder because of the tax disadvantage they create, which results in lower value.

Velnampy.T (2013) studied on the corporate governance and firm performance and used samples of 28 manufacturing companies and times periods of 2007 - 2011 state that determinants of business ethic not correlated to the performance measures of the company. Regression model signify that corporate governance don't affect companies performance (ROE and ROA).

Velnampy. T and Nimalathasan, B. (2009) studied on the relation between organizational growth and profitability of Commercial bank in Sri Lanka the period of the studies10 years from 1997 to 2006. They found that, sales are positively associated with profitability ratios except operating profit, return on equity and number of depositors are negatively correlated to the profitability ratios except operating profit and return on equity. Likewise, number of advances is also negatively correlated to the return on average shareholders' funds.

Amidu (2007) studied on the dividend policy affects firm performance which is measured by the return on assets (ROA). The studied showed that the significant relationship between return on assets (ROA), return on equity (ROE), growth in sales and dividend policy. The results showed that a statistically significant relationship between profitability and dividend payout ratio.

DOI Number: https://doi.org/10.30780/IJTRS.V05.I09.001

pg. 1

Www.ijtrs.com

www.ijtrs.org

Paper Id: IJTRS-V5-I4-002

Volume V Issue IX, September 2020

@ 2017, IJTRS All Right Reserved 


\section{OBJECTIVE OF THE STUDY}

Fundamental analysis of public and private sector banks in India has been done with the objective to analyzing the future profitability position of the selected banks which is helpful in taking investment decisions. So the two main following objectives are:

$>$ To find out which company fundamentally suitable for investment?

$>$ To find out which company batter future?

\section{METHOD OF THE STUDY}

In this study used the bank sector's one private and another public listed bank such as: HDFC and SBI. The period of the study selected nine years from 2000 to 2019. Used t-test two samples variance for the aim of relevancy of the studied with considered variable, and on the other hand, used graph and chart for simply clarification the motivation of the variable. And other side, performance measure tool used wear: return on assets, return on equity, dividend per share and net profit margin of the company.

\section{DATA ANALYSIS}

In the study considered two bank one is private bank and another one is public bank such as : HDFC and SBI bank which is listed in national stock exchange. So first of all looked up the growth of bank industry in stock exchange and compare with HDFC bank growth.

\begin{tabular}{ll|ll|} 
HDFC BANK & -NSE & BANK NIFTY & - BSE \\
\cline { 5 - 6 } & (244.62\%) & $3,531.75$ & (29.22\%) \\
\hline 117.17 &
\end{tabular}
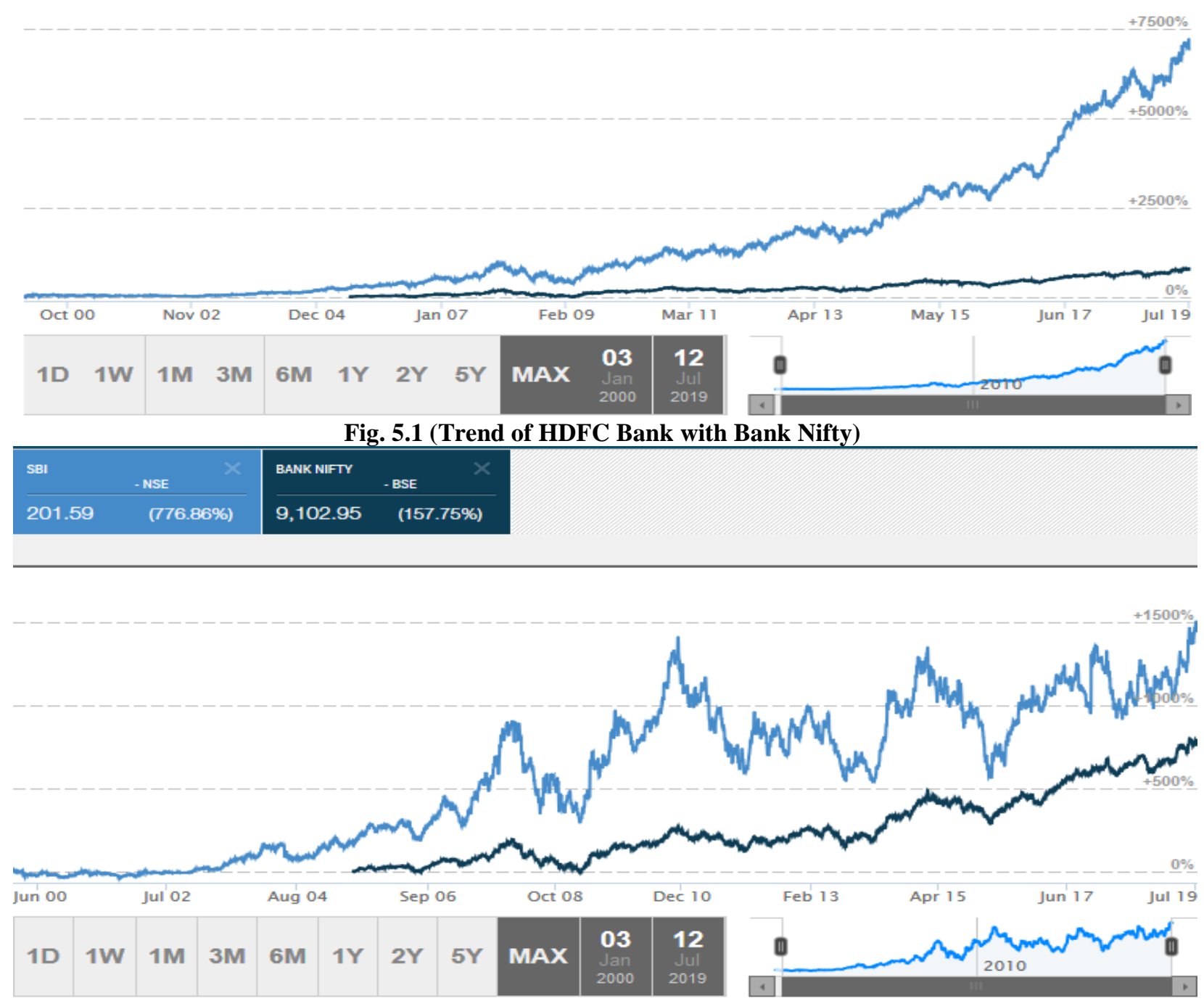

Fig. 5.2 (SBI Bank and Bank Nifty Trend)

DOI Number: https://doi.org/10.30780/IJTRS.V05.I09.001

pg. 2

www.ijtrs.com

www.ijtrs.org 


\section{7 $\mathbb{R} \leqq$ International Journal of Technical Research \& Science}

And on the other hand if we compare the bank nifty and SBI bank growth, than a clear picture came in front of generalization the HDFC bank growth comparatively good signal than the SBI growth. So it's the basic question why those kinds of situation raised. For that purpose the journey of this study to find out the main cause of the imbalance the growth of the trend.

\begin{tabular}{lr|lr}
\hline SBI & -NSE & HDFC BANK & - BSE \\
\cline { 5 - 6 } 219.63 & (855.33\%) & 323.00 & (826.03\%)
\end{tabular}

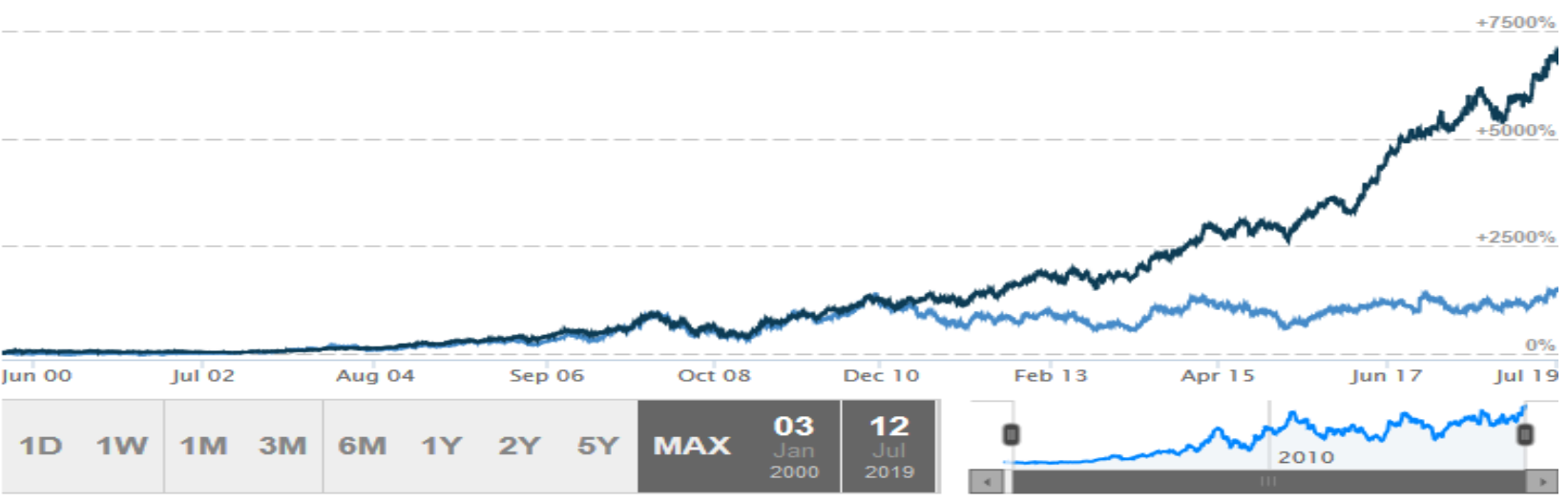

Fig. 5.3 (SBI Bank and HDFC Bank Trend)

And on the other point of view if we show the above picture of the trend line, one conclusion is clear that over the long run of period since nineteen years the growth of HDFC bank is very attractive with the compare SBI bank.

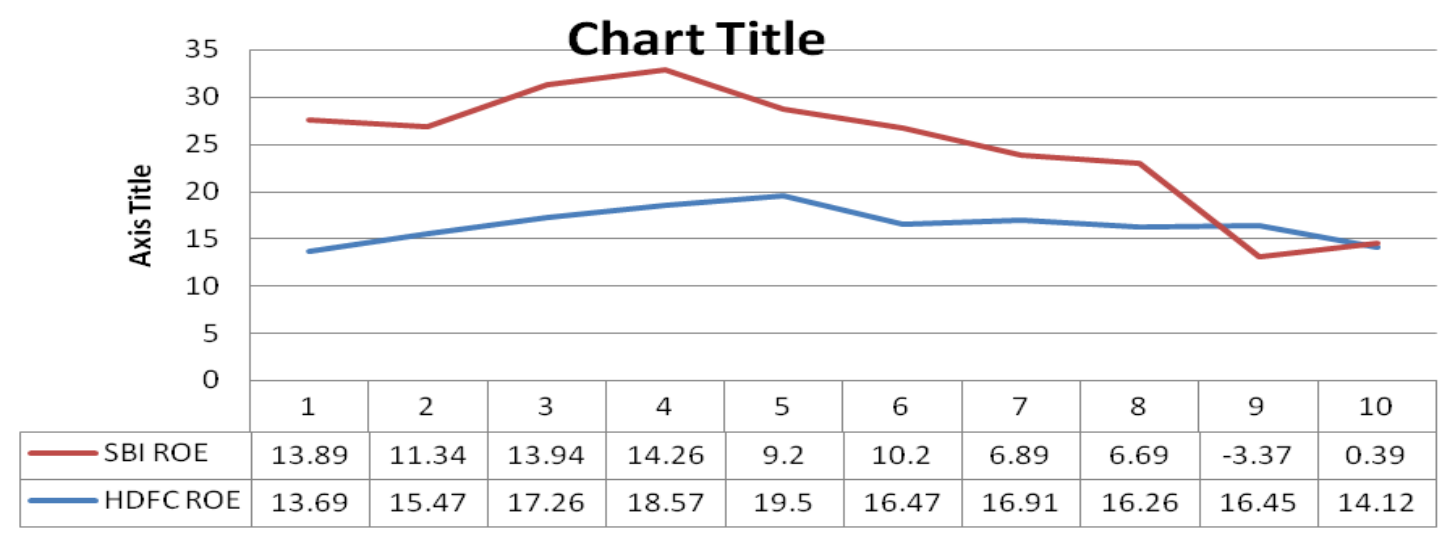

Fig. 5.4 Chart Line on Roe from Two Bank

Table-5.1 F-Test Two-Sample for Variances

\begin{tabular}{|l|c|c|}
\hline \multicolumn{1}{|c|}{ Mean } & SBI ROE & HDFC ROE \\
\hline Variance & 16.47 & 9.226667 \\
\hline Observations & 3.189333 & 9 \\
\hline Df & 10 & 8 \\
\hline F & 9 & \\
\hline P(F<=f) one-tail & 0.104022 & \\
\hline F Critical one-tail & 0.001333 & \\
\hline
\end{tabular}

Return on equity (ROE) is a measure of financial performance calculated by dividing net income by shareholders' equity. Because shareholders' equity is equal to a company's assets minus its debt, ROE could be thought of as the return on net assets. According to the data analysis the ROE is significant role for this study, because F- test for two sample P-value is less than 0.05 and F-critical value more than calculated value. In the graphical representation and statistical analysis say that HDFC bank's performance batter ten SBI bank. 
ᄀ $\square$ R 5 International Journal of Technical Research \& Science

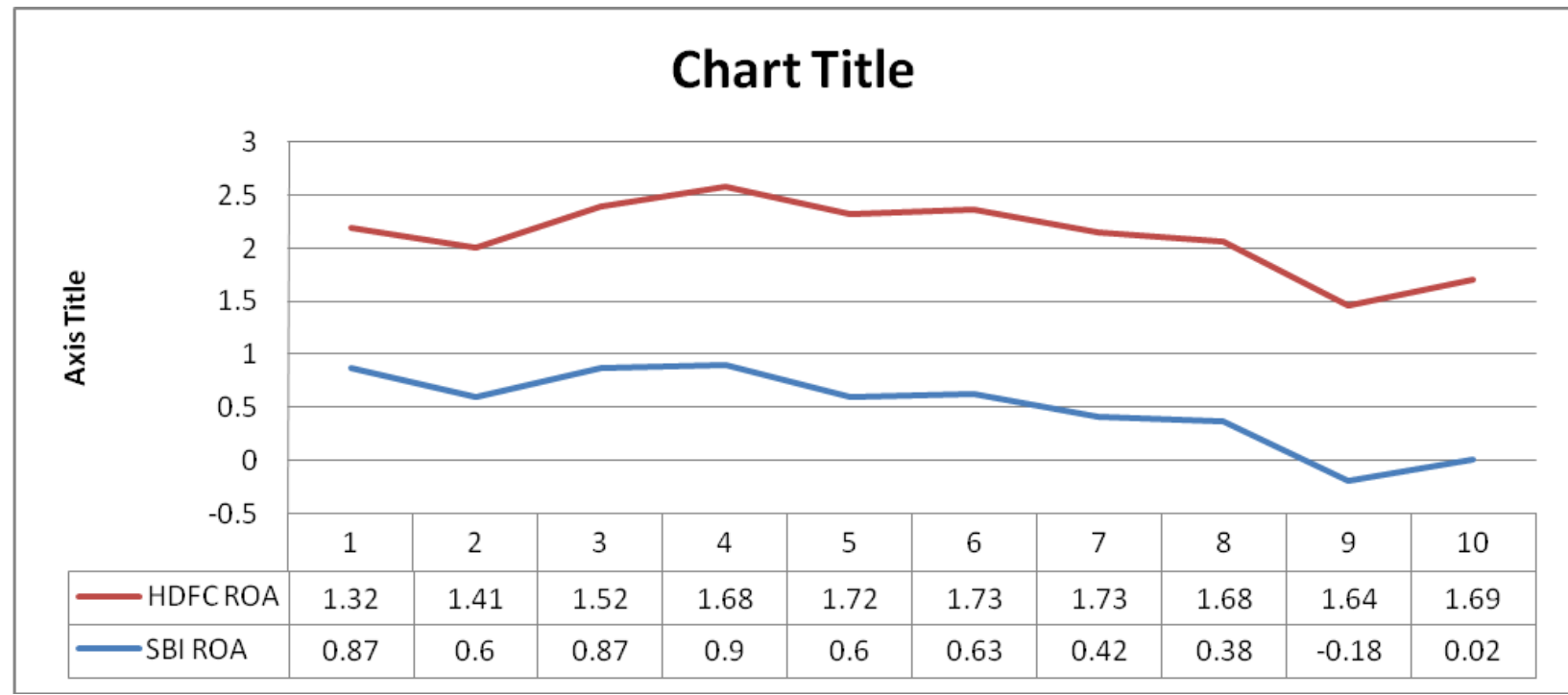

Fig. 5.5 Chart Line on Roa from two Bank

Table-5.2 F-Test Two-Sample for Variances

\begin{tabular}{|l|c|c|}
\hline \multicolumn{1}{|c|}{ Mean } & SBI ROA & HDFC ROA \\
\hline Variance & 0.511 & 1.612 \\
\hline Observations & 0.131454 & 0.021129 \\
\hline df & 10 & 10 \\
\hline F & 9 & 9 \\
\hline P(F<=f) one-tail & 6.22155 & \\
\hline F Critical one-tail & 0.005963 & \\
\hline & 3.178893 & \\
\hline
\end{tabular}

Return on assets (ROA) is an indicator of how profitable a company is relative to its total assets. ROA gives a manager, investor, or analyst an idea as to how efficient a company's management is at using its assets to generate earnings. Return on assets is displayed as a percentage. According to the data analysis the ROA is significant role for this study, because F- test for two sample P-value is less than 0.05 and F-critical value more than calculated value. In the graphical representation and statistical analysis say that HDFC bank's performance same like SBI bank.

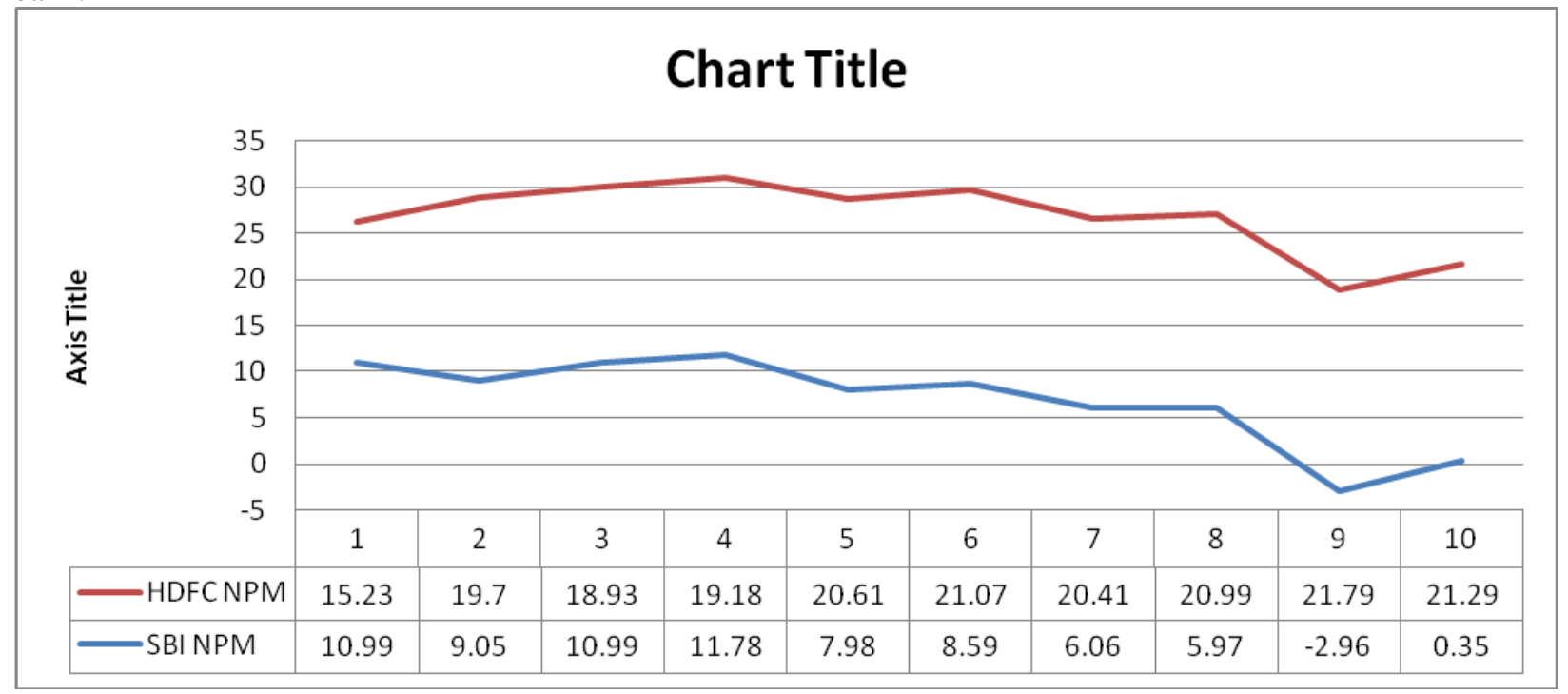

Fig. 5.6 Chart Line on NPM from two Bank 


\begin{tabular}{l}
\multicolumn{1}{l|}{ T \begin{tabular}{c|c|} 
S International Journal of Technical Research \& Science \\
Table-5.3 F-Test Two-Sample for Variances
\end{tabular}} \\
\begin{tabular}{|l|c|c|}
\hline & SBI NPM & HDFC DIV \\
\hline Mean & 6.88 & 19.92 \\
\hline Variance & 23.06713 & 10 \\
\hline Observations & 10 & 9.569956 \\
\hline Df & 9 & \\
\hline F & 6.461462 & \\
\hline P(F<=f) one-tail & 0.005221 & \\
\hline F Critical one-tail & 3.178893 & \\
\hline
\end{tabular}
\end{tabular}

The net profit margin is equal to how much net income or profit is generated as a percentage of revenue. Net profit margin is the ratio of net profits to revenues for a company or business segment. Net profit margin is typically expressed as a percentage but can also be represented in decimal form. The net profit margin illustrates how much of each dollar in revenue collected by a company translates into profit. . According to the data analysis the ROA is significant role for this study, because F- test for two sample P- value is less than 0.05 and F-critical value more than calculated value. In the graphical representation and statistical analysis say that HDFC bank's performance same like SBI bank.

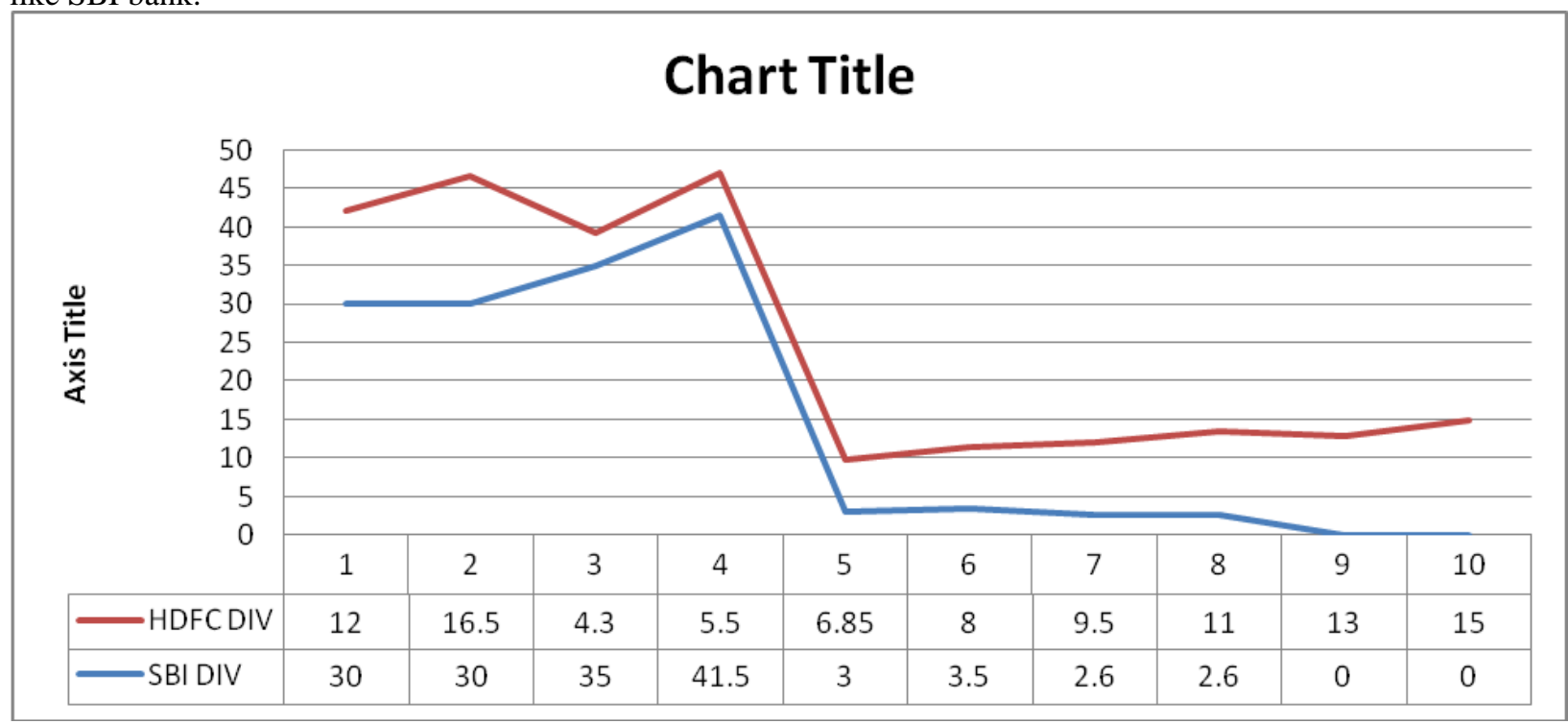

Fig. 5.6 Chart Line on DIV from two Bank

Table-4 F-Test Two-Sample for Variances

\begin{tabular}{|l|c|c|}
\hline & SBI div & HDFC div \\
\hline Mean & 14.82 & 10.165 \\
\hline Variance & 287.2996 & 16.43225 \\
\hline Observations & 10 & 10 \\
\hline Df & 9 & 9 \\
\hline F & 17.48388 & \\
\hline P(F<=f) one-tail & 0.000113 & \\
\hline F Critical one-tail & 3.178893 & \\
\hline
\end{tabular}

Dividend per share (DPS) is the sum of declared dividends issued by a company for every ordinary share outstanding. The figure is calculated by dividing the total dividends paid out by a business, including interim dividends, over a period of time by the number of outstanding ordinary shares issued. A company's DPS is often derived using the dividend paid in the most recent quarter, which is also used to calculate the dividend yield. According to the data analysis the dividend per share is significant role for this study, because F- test for two sample 
J $\mathrm{R} \leqq$ International Journal of Technical Research \& Science

$\mathrm{P}$ - value is less than 0.05 and F-critical value more than calculated value. In the graphical representation and statistical analysis say that HDFC bank's performance batter ten SBI bank.

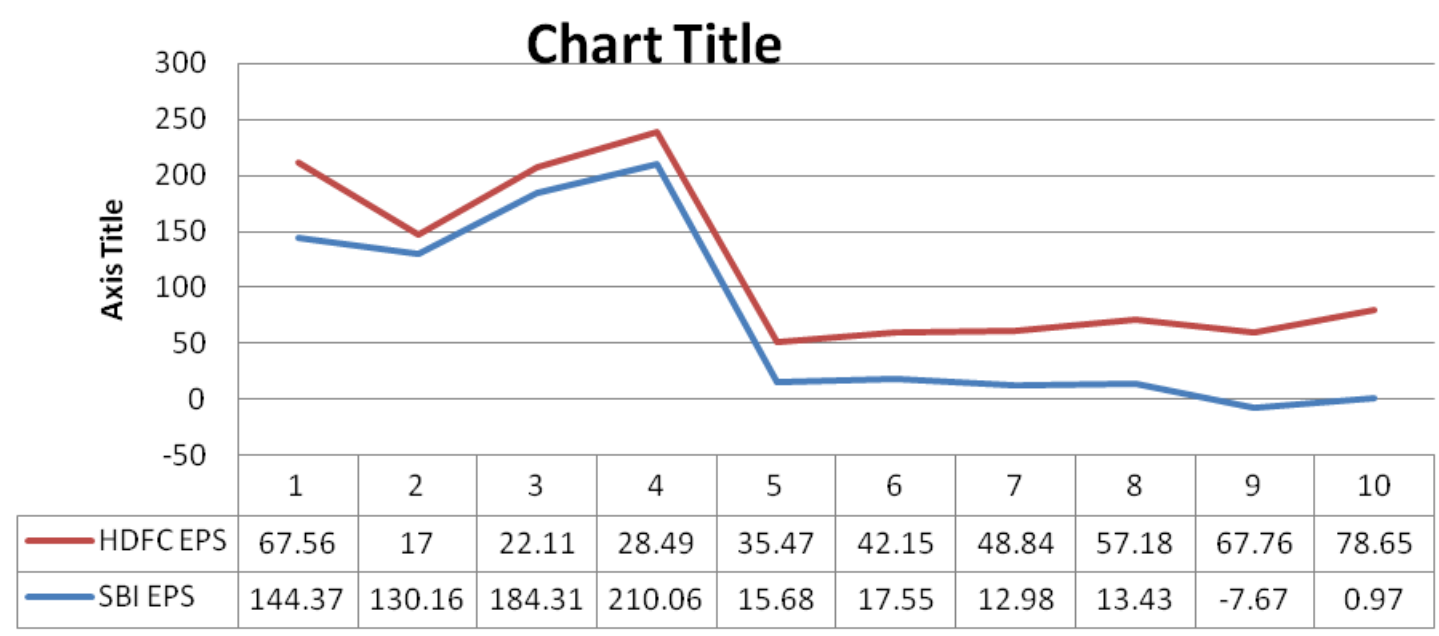

Fig. 5.6 Chart Line on EPS from two Bank

Table-5 F-Test Two-Sample for Variances

\begin{tabular}{|l|c|c|}
\hline & SBI EPS & HDFC EPS \\
\hline Mean & 72.184 & 46.521 \\
\hline Variance & 7192.987071 & 442.0814 \\
\hline Observations & 10 & 10 \\
\hline Df & 9 & 9 \\
\hline F & 16.27072875 & \\
\hline P(F<=f) one-tail & 0.000151186 & \\
\hline F Critical one-tail & 3.178893105 & \\
\hline
\end{tabular}

Earnings per share (EPS) calculated as a company's profit divided by the outstanding shares of its common stock. The resulting number serves as an indicator of a company's profitability. It is common for a company to report EPS that is adjusted for extraordinary items and potential share dilution. The higher a company's EPS, the more profitable it is considered. According to the data analysis the EPS is significant role for this study, because F- test for two sample P- value is less than 0.05 and F-critical value more than calculated value. In the graphical representation and statistical analysis say that HDFC bank's performance batter ten SBI bank.

\section{CONCLUSION}

The study focused on the fundamental analysis of different company with the same sector or industry. The prime objective of this study are to find out the best future perspective and expected good future growth compare to other with the based on historical performance. Selected two banking company which is listed in Indian stock exchange and over the ten year financial data. Considered four indicator of barometer of the companies are: earning per share, dividend per share, return on equity and return on assets. Used mean difference of each variable for the purpose of testing the significant of the variable of this study. On the basis of the financial data and limited period of the study might be concluding that private bank focused good signal then public bank. But in our study conducted very small sample only two bank, in case of large sample it's may be opposite result.

\section{REFERENCE}

[1] Das, Abhiman \& S. Ghosh. (2006). Financial Deregulation and Efficiency: An Empirical Analysis of Indian Banks during the Post Reform Period. Review of Financial Economics, Vol. 15(3), 193-221.

[2] Dwivedi. Amit Kumar \& Charyulu D. Kumara. Efficiency of Indian Banking Industry in the Post- Era Working Paper 2011-03-01 March 2011IIMA.

[3] Davda, Nishit V (2012). A Comparative Study of Selected Private Sector Banks in India. International Journal of Research in Commerce and Management, Vol. 3(7), 161-165. 
7 ᄀ $\square$ R $S$ International Journal of Technical Research \& Science

[4] Gupta Omprakash K., Doshit Yogesh, and Chinubhai Aneesh. (2008). Dynamics of Productive Efficiency of Indian Banks. International Journal of Operations Research Vol. 5 (2), 78-90.

[5] Jensen M (1986). Agency costs of free-cash-flow, corporate finance, and takeovers. Am. Econ. Rev., 76: 323329.

[6] Jensen MC, Meckling W (1976). Theory of the Firm: Managerial Behavior, Agency Costs, and Ownership Structure. J. Financ. Econ.,3: 305-360.

[7] Jensen G, Solberg D, Zorn T (1992). Simultaneous determination of insider ownership, debt, and dividend policies. J. Financ. Quant. Anal., 27: 247-263.

[8] Amidu, M and Abor, J. (2006). Determinants of dividend payout ratios in Ghana, The Journal of Risk Finance,vol. 7(2), pp 135-145

[9] Farsio, F., Geary, A., \& Moser, J. (2004). The relationship between dividends and earnings. Journal for Economic Educators, 4(4), $1-5$.

[10] Lie, E. (2005). Financial flexibility, performance, and the corporate payout choice. The Journal of Business, $78(6), 2179-2202$.

[11] Modigliani and Miller (1961): "Dividend Policy, Growth and the Valuation of shares". Journal of Business. PP-411.

[12] Tahir, A. and N. Raja, 2014. The impact of dividend policy on shareholders' wealth. International Journal of Business and Management, 16(1): 24-33. 